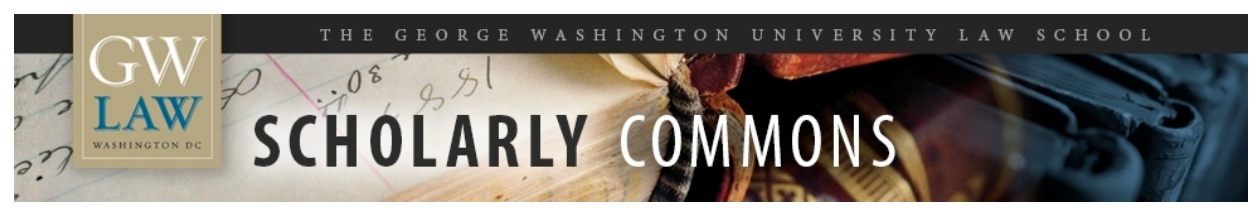

\title{
Communicating Governance: Will Plain English Drafting Improve Regulation?
}

Steven L. Schooner

George Washington University Law School, sschooner@law.gwu.edu

Follow this and additional works at: https://scholarship.law.gwu.edu/faculty_publications

Part of the Government Contracts Commons

\section{Recommended Citation}

Review of Writing Readable Regulations, by Thomas A. Murawski. 70 George Washington University Law Review 163-180 (2002).

This Book Review is brought to you for free and open access by the Faculty Scholarship at Scholarly Commons. It has been accepted for inclusion in GW Law Faculty Publications \& Other Works by an authorized administrator of Scholarly Commons. For more information, please contact spagel@law.gwu.edu. 


\title{
THE GEORGE WASHINGTON UNIVERSITY LAW SCHOOL
}

\author{
Public Law and Legal Theory Working Paper No. 031 \\ 2001
}

\section{COMMUNICATING GOVERNANCE: \\ W ILL PLAIN ENGLISH DRAFTING IMPROVE REGULATION}

Steven L. Schooner

George Washington University Law Review, volume 70, no. 1, 2002

This paper can be downloaded without charge from the Social Science Research Network Electronic Paper Collection: http:// papers.ssrn.com/abstract $=291584$ 


\section{Review Essay:}

\section{Communicating Governance:}

\section{Will Plain English Drafting Improve Regulation?}

Writing Readable Regulations by Thomas A. Murawski, Durham: Carolina Academic Press, Pp. xiv, 152.

Steven L. Schooner ${ }^{* *}$

\section{Introduction:}

\section{Why Would You Read A Book About Readable Regulations? ${ }^{1}$}

The orderly transition of power from the Clinton to Bush administration signals the end of Vice President Gore's ambitious, high profile National Performance Review (NPR), later renamed the National Partnership for Reinventing Government. ${ }^{2}$ Although the NPR attracted its share of critics, it gener ally received kudos for, among other things, focusing attention upon the

* Principal, The Murawski Group <http://www.writingandspeaking.com/ $>$ (visited November 1, 2000), formerly Professor of English, United States Air Force Academy.

** Associate Professor, George Washington University Law School. The author thanks Heidi M. Schooner and Amy E. Sloan for their helpful comments. Colleen F. Dowd and Kara Haberbush contributed valuable research assistance.

${ }^{1}$ As discussed below, one of the trademarks of the plain language movement's trademarks is reliance upon question-and-answer format. Murawski encourages drafters to "use $I$ questions and you answers in regulations." Thomas A. Muraw ski, Writing Read Able Regulations 33 (1999). In an effort to reflect the spirit of the plain language movement, I attempted to adopt these techniques throughout this review.

2 Stephen Barr, Members of Campaign to Reinvent Government Packing Up, Not Giving Up, Wash. Post, Jan. 14, 2001, at C2.

This draft, forthcoming in 70 GEO. WASH. L. REV. (2002), is reprinted with permission of the George Washington Law Review. 
plain language movement. ${ }^{3}$ While it would be hyperbole to suggest that the NPR's efforts dramatically improved the clarity of the government's written communication (including statutes, regulations, policies, instructions, etc.), some progress was made. ${ }^{4}$

Nothing suggests that the Bush administration will accept the NPR's torch. ${ }^{5}$ The new administration confronts a diverse menu of problems from which to choose. The mechanics of drafting - at its worst, characterized as a matter of style as opposed to substance - is not likely to just ify prompt efforts to implement or effectuate po licy. ${ }^{6}$ Fortunately, the plain language movement appears at least to have begun taking root in numerous agencies. ${ }^{7}$ And, even though

3 The NPR "won high marks for streamlining the way the government buys goods and services, for promoting 'customer service' and 'plain language' regulations, and for tossing out silly rules. It was heavily criticized for failing to overhaul outdated civil service laws and for downsizing the federal work force." Barr, supra note 2. For an extensive assessment of the NPR's most visible success story, re forming the government's acquisition process, see Steven L. Schooner, Fear of Oversight: The Fundamental Failure of Businesslike Government, 50 AM. U. L. REv. 627 (2001).

${ }^{4}$ See Jason Peckenpaugh, Clinton Administration Awards Last Plain Language Prize, at $<$ http://www.govexec.com/dailyfed/0101/010801p1.htm>. The NPR awarded monthly "No Goggledygook" plain language awards, which highlighted particularly successful efforts, through January 2001.

5 "Because the reinvention emerged as one of Gore's signature projects, it se ems likely the Bush administration will let the reform effort disappear." Barr, supra note 23.

${ }^{6}$ The Bush administration "is hamstrung by the huge list of new regulations issued by the Clinton administration during the eight years it controlled the executive branch, especially the 25,000 pages of rules agencies sent to the Federal Register in the last few months of Clinton's second term." Cyril T. Zaneski, Escape Artist: George W. Bush Attempts to Break the Clintonian Regulatory Knot, 33 Gov'T EXecutive 26 (Mar. 2001).

7 A WESTLAW search reveals that, during 2000 the Federal Register included more than 630 documents that referenced "plain English" or "plain language." During 1999 more than 410 documents contained one or both of these phrases. Some of these - a distinct minority- do not reflect efforts to improve clarity in drafting. For example, some Federal Register documents refer 
the plain language movement lost its most well-placed executive branch advocate, champions outside the government may fill the void. In that context, Thomas A. Murawski's WRITING READABLE REGULATIONS is poised to make a valuable contribution.

\section{Why Focus Upon How Regulations Are Written?}

Regulations merit attention because they pervade most conceivable activities in our lives. Murawski explains that he focuses on regulations " $[\mathrm{b}]$ ecause they are so important to the public's health, safety, and productivity and to the government's credibility." ${ }^{\prime}$

Government regulation is as ubiquitous as it is seemingly chaotic. From grazing fees to toxic waste clean-up and from financial institutions to welfare and education, virtually no part of society or of our lives is untouched by government. What we eat, how we vote, and what we listen to on the radio or watch on television are each affect ed by government regulation. ${ }^{9}$

Accordingly, regulations are very important. Despite all of the (appropriate) attention lavished upon the Constitution and Congressionally enacted statutes, regulation provides the most visible and concrete manifestation of how the government expects individuals, businesses, and other organizations to behave.

\footnotetext{
${ }^{7}$ (...continued)
}

to matters of statutory interpretation, e.g., whether a proposed regulation reflects "the pla in language of a statute."

${ }^{8}$ MURAW SKI, supra note 1 at ix.

9 Joseph P. Tomain \& Sidney A. Shapiro, Analyzing Government Regulation, 49 ADMIN. L. REV. 377, 377-78 (1997) (discussing, among other things, the distinction between traditional administrative law scholarship - addressing "how legal procedures are and should be used to establish fair, efficient, and accountable administrative decisionmaking" - and government regulation scholarship - studying "what we can and should expect of and receive from the machinery of government"). 
Granted, the plain language movement aspired to improve all of the go vernment's public written communication. Murawski's charter, however, is more limited. ${ }^{10}$ Nonetheless, there are efficiencies associated with focus, and I sense that Murawski has chosen his target wisely. As students of the legislative process often conclude, to ho pe for significant improvements in the clarity of legislative drafting is a flight of fancy. ${ }^{11}$ Clarity and precise prose rarely prevail when drafting is pressured and adversely impacted by diverse external inputs, hurried mark-ups, eleventh-hour amendments, constraints asso ciated with drafting around the existing code, or the rigors of the committee and conference structure. ${ }^{12}$ I suspect that regulation drafting, while also a convoluted and at times contentious process, is more susceptible to quality control, editing, and improvement, specific ally in the cont ext of clarity. ${ }^{13}$ Similarly, it seems reasonable to focus on the

${ }^{10}$ In all fairness, Murawski asserts that his book can be applied to most government written work product. "This book shows you how to write any policy or procedure in plain language - a federal regulation on nuclear waste, a sta te po licy on child support, a company manual on driving warehouse forklifts." MURAW SKI, supra note 1 at ix.

11 This harsh reality underscores the difficulty in adopting universally accepted cannons of statutory interpretation. "How can a large group of people have any specific, actual intent about the meaning of words used in a statute? A majority vote might only have been possible because the members of the enacting coalition understood its vague or ambiguous language in very different ways or because they had different expectations regarding the ways courts would fill statutory gaps." William N. EsKRidge, JR. et Al., Legislation AND STATUtory INTERPRETATION 6 (2000).

${ }^{12}$ For a quasi-o fficial, yet accessible summary of the legislative process, see Charles W. Johnson, How Our Laws Are Made <http://thomas. loc. gov/ho me/lawsmade. to .html $>$ (Johnson is the United States House of Representatives Parliamentarian); and Robert B. Dove, Enactment of a Law <http://thomas.loc.gov/home/enactment/enactlawtoc.html $>$ (Dove is the United States Senate Parliamentarian). For a less procedural game theory model, see generally, William Eskridge, Jr. \& John Ferejohn, The Article I, Section 7 Game, 80 Geo. L.J. 523 (1992).

${ }^{13}$ Some may find this distinction overblown, suggesting that, as a matter of principle, there is little difference between drafting statutes, regulations, or other governmental instructions, 
Federal Register and Code of Federal Regulations, rather than the government's entire written output. By definition, regulations - many of which have the force and effect of law - take precedence over the exponentially larger body of government policy documents, directives, instructions, and publications. ${ }^{14}$ Unfort unately, most regulations are written by attorneys, and

${ }^{13}$ (...continued)

guidance, or policy documents.

Legal drafting is the crystallization and expression in definitive form of a legal right, privilege, function, duty, or status. It is the development and preparation of legal instruments such as constitutions, statutes, regulations, ordinances, contracts, wills, conveyances, indentures, trusts, and leases.

[It] differ[s] from the preparation of documents such as briefs and pleadings [in that it] seeks a degree of precision and internal coherence rarely met outside the language of formal logic or mathematics. Second, it is almost exclusively nonemotive ....

Reed Dickerson, The Fundamen tals of Legal Drafting 4-6 (1965) (citations omitted).

${ }^{14}$ While his book's title suggests a focus upon the Federal Register and the Code of Federal Regulations, Murawski's target audience, consistent with the NPR's plain language effort, is broader than the Federal Register and the Code ofFederal Regulations. Murawski seeks to address all government employees who draft any rules that affect the public. Accordingly, I assume that the plain language effort is intended to apply to all regulations, regardless of whether notice or comment procedures are required, thus reaching both legislative rules and interpretive rules. For a helpful discussion of the dist inctions between these types of rules, see generally, Richard J. Pierce, Jr., Distinguishing Legislative Rules from Interpretative Rules, 52 ADmIN. L. Rev. 547 (2000); Robert A. Anthony, A Taxonomy of Federal Agency Rules, 52 Admin. L. Rev. 1045 (2000); Peter L. Strauss, The Rulemaking Continuum, 41 Duke L.J. 1463 (1992); Robert A. Anthony, Interpretive Rules, Policy Statements, Guidances, Manuals, and the Like -Should Federal Agencies Use Them to Bind the Public?, 41 Duke L.J. 1311 (1992); Michael Asimow, Nonlegislative Rulemaking and Regulatory Reform, 1985 DukE L.J. 381. See also William S. Jordan, III, Ossification Revisited: Does Arbitrary and Capricious Review Significantly Interfere with Agency Ability to Achieve Regulatory Goals Through Informal Rulemaking?, 94 Nw. U. L. REV. 393 (2000) (suggesting that hard look review neither stifles, nor deters informal 
conventional wisdom suggests that at torneys "do not write plain English[, but instead] ... use arcane phrases[, and $] \ldots$ become redundant [and] . . verbose. $" 15$

\section{Why Did I Choose This Book?}

I chose to review Murawksi's book for a number of reasons. First, in the spirit of full disclosure, I frequent ly had the opportunity, while serving at the Office of Management and Budget (OMB), to observe Tom Murawski ply his craft. I watched Murawski train budget analysts, economists, policy wonks, and attorneys to improve their written communication and, possibly more importantly, coach supervisors and executives to elevate the quality of the ir organization's written work product. ${ }^{16}$ Second, Writing READABLE REgulations applies and expands upon the theme found in Richard C. Wydick's now ubiquitous, but deservedly popular, Plain English FOR LaWYers. ${ }^{17}$ Third, and most importantly, I think the public would be well

\section{rulemaking).}

${ }^{14}(\ldots$ continued $)$

15 Richard C. Wydick, Plain English for Lawyers 3 (4th ed. 1998).

16 I was particularly impressed by Murawski's suggestion that supervisors resist any editing when first reading a subordinate's or colleague's draft. This discipline forces the reader to focus upon the document's content. Specifically, it reduces the risk that the reader will become distracted by organizational, style, or technical inadequacies, which can be more readily remedied. Although many superviso rs initially found such an approach challenging, most later conceded the wisdom of the practice.

17 WyDICK, supra note 15. While I recommend Wydick's book, I do not mean to suggest that it has cornered the market. For a different approach, see MARY BARNARD RAY \& JiLL J. RAMs field, Legal Writing: Getting It Right and Getting It Written (3d ed. 2000). In addition, I unhesitatingly continue to recommend, to both legal and lay readers, WILLIAM Strunk, Jr. \& E.B. White, The Elements of Style (4th ed. 2000). For those seeking a broader resource, I suggest William Zinsser, On Writing Well: The Classic Guide to Writing NONFICTION (6th ed. 1998). 
served if Congress required all regulatory drafters to use this book. Finally, I see Murawski's

book as a proxy for the burgeoning literature spawned by the plain language movement.

Lawyers who serve businesses and government agencies have learned that using plain language pays dividends: understandable warranties help sell products, and understandable government forms require less staff time to explain and reduce the number of errors made by those who fill them out. ${ }^{18}$

\section{What Other Plain Language Initiatives Remain?}

An extensive legacy of the NPR's initiatives remains, in the form of the Plain Language Action Network. ${ }^{19}$ Further, many agencies made plain language drafting part of their regulatory regime pursuant to President Clinton's June 1, 1998 Presidential Memorandum. The memorandum requires agencies to use plain language principles in proposed rules, final rulemakings, and all new documents that "explain how to obtain a benefit or service or how to

${ }^{18}$ Wydick, supra note 15 , at 4 (citations omitted). A similar, yet arguably more critical message, more than three decades old, is suggested by Professor David Mellnikoff: "The law in its most ordinary operations has sufficient technicality to baffle the untrained." DAVID MELlinKofF, The Language of the Law 453-54 (1963).

19 See the Plain Language Action Network (PLAN), on the National Partnership for Reinventing Government Home Page <http://www.npr. gov> (visited Oct. 21, 2000). PLAN is "a government-wide group working to improve communications from the federal government to the public." Plain Language Action Network, <http://www.plainlanguage.gov> (visited Feb. 21, 2001). It is unclear how long this website - which does not hide its roots as an NPR initiative will survive in its current form, hosted by the General Services Administration Office of Government wide Policy. 
comply with a requirement $\ldots . .20$ The plain language initiative also received the imprimatur of cre dibility when it was incorporated into the drafting gu idance for Federal Register material. ${ }^{21}$ Individual agencies and government instrumentalities also led by example. One of the most widely disseminated government drafting guides is the Securities and Exchange Commission's publication: A Plain English Handbook: How to Create Clear SEC Disclosure Documents. ${ }^{22}$ The American Bar Association further infused energy into the effort by urging "agencies to use plain language in writing regulations, as a means of promoting the understanding

${ }^{20}$ See Presidential Memorandum on Plain Language, $<$ http ://www.pla inlanguage.gov/cites/memo.htm $>$ (visited October 21, 2000) ("By u sing plain language, we send a clear message about what the Government is do ing, what it requires, and what services it offers."). 63 Fed. Reg. 31885 (1998). See also Vice President Al Gore, Memorandum Implementing the Presidential Memorandum on Plain Language, (July 29, 1998) $<$ http://www.plainlanguage.gov/vpguid.htm>.

21 Agencies that submit regulatory text to the Federal Register should be familiar with the National Archives and Record Administrations (NARA's) Guidance on Making Regulations Readable. See $<$ http://www.nara.gov/fedreg/mrr.html $>$ (visited October 21, 2000).

${ }^{22}$ See A Plain English Handbook: How to Create Clear SEC Disclosure Documents, $<$ http://www.sec.gov/pdf/handbook.pdf $>$ (visited October 21, 2000). See also Federal Acquisition Regulation Drafting Guide, <http://www.arnet.gov/far/draft ingguide.htm> (implementing the presidential plain language memorandum and "encourag[ing] clear and simple writing using - Active voice; Short sentences and paragraphs; Vert ical lists; and Care in using and placing words."); the Plain Language Initiative: Federal Aviation Administration, $<\mathrm{http}: /$ www.faa.gov/language/ $>$. If you are interested enough to be reading this footnote, you might also enjoy the Environmental Protection Agency's The Plain English Guide to the Clean Air Act, EPA-400-K-93-001 (Apr. 1993), $<$ http://www.epa.gov/airprogm/oar/oaqps/peg_caa/pegcaain.html $>$. 
of legal obligations . ..."23 Similar efforts are underway in Canada, the United Kingdom, and Australia. ${ }^{24}$

\section{What Is the Goal of the Plain Language Movement?}

The plain language movement pursues a simple agenda. Governments should

communicate clearly, effectively, and precisely. ${ }^{25}$ Yet, because the devil is in the details, the path

to plain language drafting is neither straight nor narrow. Moreover, the mere concept of plain

English drafting at times seems sufficiently amorphous such that daunting questions remain. For

23 See House of Delegates Approves Risk-Assessment and Plain-Language Resolutions, 25 Admin. \& REG. L. News 19 (Fall 1999), $<$ http://www.abanet.org/adminlaw/news/vol25no1/approves_risk.html $>$ (visited October 30, 2000). Although supportive, the ABA's support contains caveats.

The resolution recommends that agencies use plain language in writing regulations, as a means of promoting the understanding of legal obligations ... . [and] use such techniques as: organizing regulations for the convenience of the reader; using direct, easily understood language; writing short sentences in the active voice; and using stylistic devices such as tables and question-and-answer format. The resolution cautions agencies to take into account possible judicial interpretations, clearly state the obligations and rights of persons affected, as well as those of the agency, and identify and explain all intended changes when revising regulations.

Id. (emphasis added).

${ }^{24}$ See the U.K. site, The Plain English Campaign at <http://www.plainenglish.co.uk/>, offering, among other things, numerous examples of "gobbledygook"; the Australian site, Plain Language Plus at $<$ http://plainlanguagenetwork.org/Organizations/pep.html $>$ (visited October 21, 2000). See also The Plain Language Association International at $<$ http://PlainLanguageNetwork.org> (visited March 10, 2001).

25 See, e.g., Joseph Kimble, Writing for Dollars, Writing to Please, 7 SCRIBEs J. Legal Writing 1, 1-2 (1996-1997). Pro fessor Kimble is one of the most prolific advocates of plain language. See also Joseph Kimble, Answering the Critics of Plain Language, 5 ScRIBEs J. LeGAL Writing 51 (1994-1995); Joseph Kimble, Plain English: A Charter for Clear Writing, 9 Thomas M. Cooley L. Rev. 1 (1992). 
example, are plain English, plain language, and readability the same thing and, if not, how do they differ ${ }^{26}$ Why is the go al plain language rather than clear or concise language $?^{27}$ Does use of the word plain connote that the language should be - as available dictionary definitions offer easily understood, not beautiful or handsome, not highly cultivated, not intricate or difficult, not rich or elabo rate, ordinary, simple, straight forward, uncomplicated, unpretentious, or with little decoration or ornamentation $?^{28}$ Cynics, of course, might criticize that, if plain language merely connotes simple language, the movement is no more than a willing accomplice to dumbing down political discourse. Such a conclusion is wrong. ${ }^{29}$

${ }^{26}$ Although I prefer Murawski's use of the term "readable regulations" to "plain language regulations," the bulk of the literature uses the word "plain" to describe the output desired.

${ }^{27}$ Review of the literature advocating plain language suggests, not surprisingly, that most of these terms are synonyms, used interchangeably, to describe the same concept. For example,

Concise writing is easy on the reader. It is easily understood. It flows smoothly. It has a rhythm to it. The mind can quickly grasp its meaning....

Flowery language is acceptable in a poem, or a novel.... Shakespeare is the recognized master of the written word in his field. But is Shakespeare easy to understand? Do first-time Shakespeare readers "get the message"[? ... S]uch writing has a place, it is very beautiful, and it helps us to learn. But concise, it is not.

Carol Ann Wilson, Plain Language Pleadings 10 (1996) (Wilson's bo ok is aimed primarily at legal assistants but has broader appeal.).

${ }^{28}$ These definitions are derived from Webster's II New College Dictionary (1995) and Dictionary.com $<\mathrm{http}: / / \mathrm{www}$.dictionary.com/cgibin/dict.pl?term=plain>.

29 The Securities and Exchange Commission aptly explains that:

It does not mean deleting complex information to make the (continued...) 
Further, exactly how plain is plain? In other words, what is the hypothetical target reading level to which plain language authors aspire? Surely, what passes for plain language depends upon the audience. ${ }^{30}$ Imagine yourself attending a conference focused exclusively upon issues that interest nuclear scientists, economists, doctors, aircraft safety engineers, securities traders, or, heaven forbid, attorneys. The most precise discourse at such an event would sound like gobbledygo ok to most citizens, with good reason. Yet, even though excessive jargon use remains

\footnotetext{
${ }^{29}(\ldots$ continued $)$ document easier to understand ....
}

Plain English means analyzing and deciding what information [readers] need to make informed decisions, before words, sentences, or paragraphs are considered. A plain English document uses words economically and at a level the audience can understand. Its sentence structure is tight. Its tone is welcoming and direct. Its design is visually appealing. A plain English document is easy to read and looks like it's meant to be read.

Securities and Exchange Commission, A Plain English Handbook, supra note 22, at 5.

With statutes and regulations, the audiences may be more varied. A statute addressed primarily to government officials may need to be written differently from one addressed to a segment of the public, and a statute addressed to a highly specialized segment of the public, such as the tobacco industry, may need to be written differently from one addressed to the public at large. Unfortunately, the concept of a particular legal audience and the broader concept of the "users of the language" are complicated by the irregularity with which usages, assumptions, and values tend to be shared even within the same speech community.

Dickerson, Legal Drafting, supra note 13, at 19-20 (citations omitted). 
a primary target of plain language advocates, there are obvious efficiencies associated with utilizing the highly peculiar vocabulary to regulate that specialized field. ${ }^{31}$

\section{Where Does the Plain Language Initiative Reside in the Hierarchy of Regu latory Drafting and Review?}

As described above, numerous sources exhort agency drafters to adopt plain language principles before submitting their regulatory handiwork to the Federal Register. Yet, of the myriad rules that surround the process of promulgating regulations, it appears that the plain English mandate has not yet a chieved predominance. Whereas the introduction of a cost-benefit standard has dramatically altered the regulatory landscape ${ }^{32}$ the plain language movement has

The concepts of legal audience and users of language are further complicated because some legal instruments [such as federal income tax statutes] are not normally read or intended to be read by the persons to whom they directly apply .... [S] uch laws need not be couched in a form appropriate for easy reading by the public at large, nor do their factual presuppositions need to be made obvious to the public. It is enough that they are understood by the general government or private lawyers and accountants in the field on whom it is customary for the general public to rely.

Dickerson, Legal Drafting, supra note 13, at 20.

32 See generally Richard J. Pierce, Jr., et al., Administrative Law and Process 1415 (1999) (citations omitted):

During the last fifteen years, significant questions have been raised concerning the desirability of such extensive [regulat ory] intervention. In particular, critics have contended that the benefits of many forms of regulation are less than the costs of the regulation. Regulation is efficient when benefits exceed costs because the total value of society's resources will have been increased. By comparison, when benefits are less than costs, society is spending more money to produce a social benefit than it is worth and thereby wasting scarce resources. 
established little more than a foothold. The most frequently discussed statutes and Executive Orders that relate to executive, legislative, and judicial analysis or review of regulations prior to their promulgation lack a plain language mandate. Nonetheless, there are plentiful opportunities for all three branches of government to scrutinize pending regulations for clarity.

The executive is best situated to enforce the plain language mandate by imposing high standards for drafting and reviewing regulations before submission to the Federal Register. The President already has a regulatory gatekeeper; before agency rules appear in the Federal Register, they pass through the Office of Management and Budget's Office of Information and Regulatory Affairs (OIRA).$^{33}$ In addition to its rule clearinghouse function, OIRA could devote additional resources to editing for clarity. Notice and comment requirements permit the public to critique

${ }^{32}$ (...continued)

For an exhaustive discussion of literature and theory associated with cost-benefit analysis, see Conference, Cost-Benefit Analysis: Legal, Economic and Philosophical Perspectives, 29 J. Legal Studs. 837-1177 (June 2000).

33 See generally Pierce, Administrative Law, supra note 32, at 485-498, 487 ("the last three presidents have required proposed rules to be submitted to OMB before being published as proposed or final rules"). The primary Clinton Administration Executive Orders include Exec. Order No. 12,866, 3 C.F.R. 638 (1994), reprinted in 5 U.S.C. $\$ 601$ (note) (1994); Exec. Order No. 12,988, 3 C.F.R. 157 (1997), reprinted in 28 U.S.C. $\$ 519$ (1995). They succeed President Reagan's Exec. Order Nos. 12,498, 3 C.F.R. 323 (1985), and 12,291, 3 C.F.R 127 (1981); President Carter's Executive Order 12,044, 3 C.F.R. 152 (1978); and President Ford's Exec. Order No. 11,821, 3 C.F.R. 926 (1971-75). See generally C. Boyden Gray, Presidential Involvement in Informal Rulemaking, 56 TUL. L. REv. 863, 864-65 (1982). I do not consider this an improper encroachment; rather, I agree with Professor Pierce and others who conclude that "the President's constitutional power to influence and control executive officials provides adequate justification for OMB review." Pierce, Administrative Law, supra note 32, at 488 (citing Lloyd N.Cutler, Regulatory Mismatch and Its Cure, 96 HARV. L. Rev. 545, 553 (1982); Peter M. Shane, Presidential Regulatory Oversight and the Separation of Powers: The Constitutionality of Executive Order No. 12,291, 23 ARIz. L. REV. 1235 (1981)). 
some regulatory work product, particularly proposed rules, before those rules become effective. ${ }^{34}$ Congress also possesses a powerful arsenal with which to exert quality control over regulatory language. The 1990s witnessed expanded congressional efforts to constrain the discretion of regulators. Concurrent with the Clinton administration's regulatory reform initiatives, Congress enacted legislation intended to reform the regulatory system and enhance congressional review of executive agency rulemaking. ${ }^{35}$ For example, Congress enacted the Paperwork Reduction Act of $1995,{ }^{36}$ the Unfunded Mandates Reform Act of 1995, ${ }^{37}$ and the Small Business Regulatory

34 See generally Administrative Procedure Act, 5 U.S.C. $\S \S 551-560$ (1994).

35 See generally Daniel Cohen, S.981, The Regulatory Improvement Act of 1988: The Most Recent Attempt to Develop a Solution in Search of a Problem, 50 Admin. L. REV. 699 (1998); Daniel Cohen \& Peter L. Strauss, Congressional Review of Agency Regulations, 49 Admin. L. Rev. 95 (1997). See also Morton Rosenberg, Whatever Happened to Congressional Review of Agency Rulemaking?: A Brief Overview, Assessment, and Proposal for Reform, 51 Admin. L. REV. 1051, 1052, 1078-1083 (1999) (discussing the "New Presidentialism").

${ }^{36}$ Pub. L. No. 104-13, 109 Stat. 163 (1995) (codified at 44 U.S.C. § 3501). Congress enacted the original Paperwork Reduction Act of 1980, Pub. L. No. 96-511, 94 Stat. 2812 (codified as amended at 44 U.S.C. $\S \S 3501-3520$ ), and then amended it with the Paperwork Reduction Reauthorization Act of 1986, Pub. L. Nos. 99-500, 99-501, 99-591(?) __ Stat. (1986). The original Act sought to ensure that the government's demands served some practical purpose, did not lead to duplication of information to which the government already enjoyed access, and imposed the least burdensome alternative for collecting the information. The 1995 Act, among other things, established goals for reducing existing paperwork burdens. For a more thorough discussion, see Jeffery S. Lubbers, Paperwork Redux: The (Stronger) Paperwork Reduction Act of 1995, 49 AdmIn. L. REV. 111 (1997).

37 Pub. L. No. 104-4, 109 Stat. 48 (1995) (codified at 2 U.S.C. § 1501). This Act requires that agencies assess certain rules' anticipated costs and benefits and consider regulatory alternatives that may prove less costly or most cost-effective. For a more in depth discussion, see Daniel E. Troy, The Unfunded Mandates Reform Act of 1995, 49 Admin. L. REV. 139 (1997); Conference, Cost-Benefit Analysis, supra note 32. For suggestions on making co st-benefit analysis more meaningful, see Robert W. Hahn, How Changes in the Federal Register Can Help Improve Regulatory Accountability, 52 AdMIN. L. REV. 927 (2000). 
Enforcement Fairness Act of $1996 .^{38}$ More recently, with the Congressional Accountability for Regulat ory Information Act of 1999, the General Accounting Office will assume an oversight role with regard to "economically significant rule[s]." ${ }^{.39}$ Congress, of course, could legislate that OMB conduct pre-publication plain language reviews or reserve to itself the right to conduct such reviews before regulations became effective. Finally, of course, the judiciary frequently reviews rules once they are applied.

The thicket of mechanisms that permit the public, the executive, the legislature, and the courts to review and impact regulations before, during, and after their promulgation cannot be ignored. The regulation writer toils in the looming shadow of myriad executive, legislative, and judicial review mechanisms waiting to be unleashed by any number of potentially interested parties. Robert Kagan suggests that 'the policymaking procedures designed to protect ...

${ }^{38}$ Pub. L. No. 104-121, tit. II, 110 Stat. 857 (1996) (codified at 5 U. S.C. § 601). This Act requires that ag encies submit rules, prior to the time they become effective, to Congress and the GAO. See generally Rosenberg, supra note 35, at 1052 (noting that, since 1996, although 15,000 major and non-major rules became effective, "just eight joint resolutions of disapproval have been introduced . . ., none of which was passed by either House"). The Act also broadened the Regulatory Flexibility Act, which mandates preparation of Regulatory Flexibility Analyses to minimize the impact of new rules upon small entities. Pub. L. No. 104-121, subtit. D, 110 Stat. 864 (codified at 5 U.S.C. $§ 601$ ). For a more in depth discussion, see Thomas O. Sargentich, The Small Business Regulatory Enforcement Fairness Act, 49 Admin. L. Rev. 123 (1997); Paul R. Verkuil, A Critical Guide to the Regulatory Flexibility Act, 1982 Duke L. J. 213. See also the Small Business Adminstration's (SBA's) Office of Advocacy Home Page $<$ http://www.sba.gov/advo > (visited Oct. 20, 2000), and SBA's Regulatory Enforcement Ombudsman $<$ http://www.sba.gov/regfair $>$ (visited Oct. 20, 2000).

${ }^{39}$ [check bill title: Truth in Regulating Act of 2000(?)], Pub. L. No. 106-312, 114 Stat.1248, (2000) (amending 5 U.S.C. § 801) (establishing a three-year pilot project, funded at $\$ 5.2$ million per year). The statute permits Cong ressional committee leaders to reque st that the GAO independently evaluate economically significant rules - rules "that may have an annual effect on the economy of $\$ 100,000,000$ or more or adversely effect in a material way the economy... ." See generally Cindy Skrzycki, The Regulators: Rules About Rules, WASH. Post, Oct. 17, 2000 , at E1. 
pluralistic values seemed to [have fallen] into the hands of the Sorcerer's Apprentice, multiplying themselves beyond control." ${ }^{40}$ Yet, despite such bountiful opportunities, plain language failures rarely derail regulations.

\section{What is Murawski's Methodology?}

Murawski's book accepts as a given the value of plain language regulation. He does not belabor the case for clarity in communication between the governing and the governed. Rather, he as sumes that readers agree with his enterprise. Accordingly, he focuses upon the skills required to write regulations more clearly. He acknowledges, however, that the venture is more complex than filtering submissions to the Federal Register, because the federal government's intricate regulatory web is already spun. The challenge, as Murawski perc eives it, lies in changing, clarifying, simplifying, and, eventually, evolving the Code of Federal Regulations. ${ }^{41}$

${ }^{40}$ Robert Kagan, Adversarial Legalism and American Government, 10 J. PoL'Y AnALYsis \& MGMt. 369, (1991), referring to:

legal procedures that ... reflect ideals of pluralistic democracy the notions, for example, that public policy should be formulated and implemented only after full and fair deliberation; that meaningful attention should be given to the claims of the individuals and groups who are not politically powerful ..., and that to vindicate those values, a variety of interest groups and agencies should be able to challenge official assumptions and judgments.

Kagan correctly points out that, in promulgating regulations, considerations such as clarity of expression, effectiveness of regulation, and justice are undermined by the daunting impediment of endless review, criticism, and challenge. "For some enterprises and org anizations, avoiding the legal process becomes more salient than fighting for what they believe is the right or just result . . .. [T]his adversarial legalism also breeds legal deadlock and socially harmful inertia." Id. at

${ }^{41}$ Murawski, of course, does not limit to the federal government the application of his wisdom. Rather, he suggests that these principles equally apply to state governments and corporations. Nonetheless, he concedes that 'you'll recognize yourself most easily here if you 
The bulk of Murawski's advice revolves aro und a group of "core ideas," followed by a cadre labeled "more ideas." ${ }^{, 42}$ Many of the core ideas will resonate with plain language advocates. Some, on first glance, appear mundane - at most mechanical, and, at worst, trivial. Others simply seem odd. But, there is a method to Murawski's madness.

\section{What Are Murawski's Nine Core Ideas?}

Murawski's first core idea, "getting started," advocates use of the question-and-answer (Q\&A) format and stresses the importance of including navigational aids for the reader. While the latter tool obviously benefits the reader, the former initially seems unnatural (or, at least controversial). Yet the Q\&A format has become one of the plain language movement's defining components. ${ }^{43}$

\footnotetext{
${ }^{41}($...continued $)$

write federal regulations." MURAW SKI, supra note 1, at ix.
}

${ }^{42}$ As should be expected of such a work, the book also includes a number of annotated models, or success stories - some in before-and-after format. These models include a liability regulation, travel regulation, land regulation, safety handbook, compliance guide, subpoena, and order. In the margins, Murawski emphasizes key teaching points. MURAW SKI, supra note 1, at 94-109. Elsewhere, Murawski provides a number of exercises, followed by suggested answers with notes and comments to maximize clarity. $I d$. at 129-148.

${ }^{43}$ The Federal Register highlights the two techniques that "most improve the look and sound of a regulation" - use of: (1) Q\&A format and (2) the word "you" for whoever must comply with the regulation. National Archives and Records Administration, Making Regulations Readable $<\mathrm{http}: / / \mathrm{www} . n$ ara.gov/fedreg/mrr.html\#top $>$. With regard to the former:

Questions, with their subjects and predicates, make headings uncommonly informative. They provide a consistent way not only to ident ify topics but to say so mething about them. Many people think in questions and answers, which makes them a natural way to design sections. Writers report that questions and answers promote step-by-step thinking that helps them spot omissions. "I" questions and "you" answers help readers see where they fit into the writing. 


\section{The question-and-answer format is the most efficient way to communicate with your reader. The reader comes to your}

document with questions that he or she needs answered. It's much more efficient to anticipate the reader's questions and pose them as he or she would. By doing this, you make it easier for the reader to find information. ${ }^{44}$

To attorneys, particularly tho se long familiar (and comfortable) with navigating statutory and regulatory texts utilizing tables of contents, indices, and headings, this method seems foreign. For example, the table of contents from a Q\&A style regulation contains many more words and, on first view, appears needlessly convoluted. Yet plain language advocates maintain that, based upon empirical research, "people were able to find information much faster in the version that had questions as headings than in the version that had nouns or noun phrases as headings." 45

For purposes of this review, I accept the validity of the empirical research that supports this conclusion, rather than investigate the depth of its support. I have seen, over time, sufficient compelling examples demonstrating that convent ional modes of communication do not necessarily reflect the manner in which the public is most comfortable receiving, synthesizing, and acting upon information. ${ }^{46}$

\section{${ }^{43}(\ldots$ continued $)$}

Id.

${ }^{44}$ Writing User Friendly Documents at $9<$ http://www.plainlanguage.gov/> (select "How To," the "Writing User Friendly Documents").

45 Ginny Redish, Research on Headings, at <http://www.plainlanguage.gov/> (select "Reference Library," then "Other Resources," then "Writing Tools").

46 Two brief anecdotes may illustrate this point. In 1976, I encountered my first computer and, after experiences with punch cards, ticker tape, magnetic tape, and eight-inch diskettes, I procured my first personal computer in the early 1980s. Until well into the 1990s, hardware and software manuals followed a similar format. Loose leaf binders contained extensive 
Murawski's second core idea is "shaping sections," which encourages short sections, again following the Q\&A format. Third, Murawski focuses upon “polishing paragraphs.” He favors short paragraphs, vertical lists, and informative paragraph labels or headings. For anyone who has spent time with the Code of Federal Regulations or the Federal Register, these suggestions seem dictated by common sense. Generally, the Federal Register and the Code of Federal Regulations offer little more visual appeal than the telephone book. Frequent users of

${ }^{46}($...continued $)$

table of contents, a sophisticated index, and a number of chapters typically following a recognizable pattern, e.g., installation, getting started, basics, advanced topics, and trouble shooting. During the 1990s, however, I found that manuals no longer accompanied either hardware or software purchases. Inst ead, a single sheet, card, or on-line service walked me through installation, after which comprehensive on-line help services were available. Although I find these services eventually answer my questions, they still seem to me less accessible than the now archaic manual. Although the written word still predominates (whether reduced to paper or drawn from the ether in electronic format), the basic medium and organizational structure through which information is conveyed has evolved.

Equally telling is the evolution of assembly instructions. With two (wonderful) children, I fear that innocuous disclaimer - "some assembly required" - and frequently have the opportunity to follow manufacturer's instructions for ass embly and operation of any number of items, ranging from cribs, car seats and humidifiers to games and toys. In recent years I observed the increasing frequency with which manufacturers eschew words altogether. For example, I recently followed pictorial instructions spanning dozens of pages to assemble rather complicated toys manufactured by Playmobil and Lego. See generally the German-based Playmobil, at $<$ http://www.playmobil.com/ushomepage/usindex.htm $>$ and the Denmark-based LEGO, at $<$ http://www.lego.com/home.asp $>$. Arguably, these manufacturers reap additional advantages through pictorial representations because, as exporters, the non-verbal instructions transcend translation burdens and other cultural barriers. In the same vein, English-speaking nations have been slow to ado pt the otherwise ubiquito us non-verbal, pictorial road signs. For an entertaining global tour of non-verbal road signs, see $<$ http://www.elve.net/rco ulst.htm $>$. I offer these anecdo tes so lely to illustrate a point, rather than to suggest that they constitute compelling evidence of changed behavior. Accordingly, it is not my intent to draw sides in the debate regarding the appropriate use of narrative in legal scholarship. See generally David A. Hyman, Lies, Damned Lies, and Narrative, 73 IND. L.J. 797, 798-800 (1998) (cataloging much of the field's recent scholarship). 
these publications will appreciate Murawski's descriptively accurate advice when he coaxes drafters: "Break up walls of words."

Fourth, Murawski entreats the drafter to craft his or her voice to fit the regulation's audience. Under the core idea, "relying on you," he suggests that the drafter make the reader the focal point of the previously covered Q\&A. For example, what the reader wants to know is: "What should I do?" Accor dingly, the drafter should tell the reader: "You should sign the document and mail it to ...."47 The fifth core idea is the organizational corollary to Q\&A drafting, "using if-then tables." Murawski suggests that these tables discourage dense text that hides choices. At the same time, Murawski criticizes flow charts, which he derides as "gymnastic attempts to capture the known universe on single pages . . . .48

His sixth core principle, "explaining yourself," promotes a concept that may cause plaintiffs' attorneys to salivate, while striking fear in the hearts of agency general counsels.

${ }^{47}$ On this point, I recommend Warren Buffett's advice:

Write with a specific person in mind. When writing Berkshire Hathaway's annual report, I pretend that I'm talking to my sisters . ... Though highly intelligent, they are not experts in accounting or finance. They will understand plain English, but jargon will puzzle them. My goal is simply to give them the information I would wish them to supply me if our positions were reversed. To succeed, I don't need to be Shakespeare; I must, though, have a sincere desire to inform.

No siblings to write to? Borrow mine: Just begin with "Dear Doris and Bertie."

Warren E. Buffet, Preface, Securities and Exchange Commission, A Plain English Handbook, supra note 22 at 2.

${ }^{48}$ MuRAw SKI, supra note 1, at 44. 
Murawski encourages drafters to "generalize briefly and then explain with a concrete example."49 You do need not be an academic to appreciate the immense pedagogical value of examples in explaining concepts. Yet, in the context of judicial review of regulations or agency application of those regulations, examples become land mines. In application, the examples or illustrations become the regulation. ${ }^{50}$ Litigators and adjudicators alike recognize that use of examples creates future targets of opportunity for affected parties to challenge agencies' applications of their regulations.

The last three core ideas address significant structural challenges. Core idea seven, "managing definitions," criticizes the use of a definitions section, typically found early in many current regulations. Murawski instead prefers liberally using cross-references. ${ }^{51}$ While I understand Murawski's point, I'm a creature of habit and I know where to look for the definitions section. Accordingly, I remain skeptical of this approach. It seems inefficient to interrupt the text with the frequent cross-references required to serve a reader who - as sugge sted throughout - is not approaching the regulation in a linear manner. Conversely, his final two core ideas seem eminently reasonable. First, Murawski counsels "allowing for growth[.]" He encourages drafters

49 MurAW SKI, supra note 1 , at 45.

50 See e.g., Perry v. Martin Marietta Corp., 47 F.3d 1134, 1138-39 (Fed. Cir. 1995) ("The additional interpretive aids published by the [government] in its regulations convince us that the board and [the contract or] have correctly interpreted the regulat ory language at issue."); Boeing Company v. United States, 680 F.2d 132, 140 (Ct. Cl. 1982) (discussing the ramifications of a "modification from the draft to the final rule ... in the income tax example").

51 But see, infra text accompanying note 61 . 
to anticipate future changes by reserving numerous section numbers within parts. ${ }^{52}$ Finally, in “controlling preambles[,]" Murawski encourages the use of navigation aids. These aids should focus readers attention upon proposed regulations' key concepts or passages for which the agency desires comment. ${ }^{53}$

\section{What Are Murawski's Six Additional Ideas? ${ }^{54}$}

Murawski follows his core ideas with six subsidiary topics under the label "more ideas".:5 "precision," "active voice," “sentences," "parallelism," "economy,” and "cross-references.” Most of these are tenets of good writing, which, although easily forgotten, merit reinforcement. ${ }^{56}$

$\begin{array}{ll}\text { Precision } & \text { Murawski spurs } \\ \text { drafters to choose the } & \text { right verb, state } \\ & \text { requirements } \\ \text { positively, and repeat } & \end{array}$

key terms, ${ }^{57}$

52 Although grammatically correct, Murawski disparages this organizational scheme as inefficient, deeming it the worst arrangement, because "readers must wait until the biter end to learn what applies - all the items in the list (and) or any one item (or)." MURAW SKI, supra note 1, at 26.

53 MuRAW SKI, supra note 1, at 61.

${ }^{54}$ Murawski favors clean, well organized tabular presentation of information whenever possible. Accordingly, I thought I should try, in at least one instance, to present information in that manner.

55 Although "more" rhymes with "core," I conclude that this division serves a greater purpose. Conversely, the author does not invest heavily in explaining the distinction.

56 In the following list, I demonstrate a two-column list. I leave it to you to decide whether this presentation breaks up the page and makes the material more readable.

57 Readers may be surprised to learn Murawski discourages use of the word "shall." "To emphasize obligation, use the widely understood must, not the outdated shall." MURAW SKI, 


$\begin{array}{ll}\text { Active Voice } & \begin{array}{l}\text { Murawski warns: "Passive } \\ \text { voice twists sentences, hides } \\ \text { responsibility, and encourages } \\ \text { wordiness." }\end{array} \\ & \begin{array}{l}\text { Murawski advocates } \\ \text { short, efficient } \\ \text { sentences, with verbs } \\ \text { promptly following } \\ \text { nouns. }\end{array} \\ & \begin{array}{l}\text { Murawski asserts that } \\ \text { "consistency sets up }\end{array} \\ \text { Parallelism } & \begin{array}{l}\text { expectations that } \\ \text { make reading easy." }\end{array} \\ & \begin{array}{l}\text { Muraws } \\ \text { no more words than it deserves." }\end{array} \\ \text { Economy } & \begin{array}{l}\text { Murawski implores } \\ \text { drafters to group } \\ \text { related ideas, which } \\ \text { should reduce the }\end{array} \\ \text { Cross-References }\end{array}$

${ }^{57}(\ldots$ continued $)$

supra note 1 , at 69.

58 MurAW SKI, supra note 1 , at 73.

59 MURAW SKI, supra note 1 , at 81 .

60 "The longer you take to say things, the more you risk blurring your ideas and inviting readers to misinterpret or, worse, just give up and just wing it." MURAW SKI, supra note 1, at 81. Fort unately, the author concedes that: "S imple writing isn't simple-minded; it's complex, sophisticated business." Id. at 87. Nonetheless, the plain language movement preaches that "less is more." For example, in 1997 the NPR recognized the Small Business Administration's Regulatory Reform Team for reducing the agency's regulations from 548 to 246 pages. Remarks by Bob Stone, Small Business Administration Hammer Award, Indian Treaty Room, Old Executive Office Building, Feb. 5, $1997<$ http://www.npr.gov/library/speeches/hammer.htm〉. 
need for cross-

references. ${ }^{61}$

\section{Would Application Of Murawski's Advice Make a Difference?}

It is impracticable to suggest that Murawski's book or, for that matter, any competing publication, is a panacea. ${ }^{62}$ The scope of the enterprise - changing the way governments write renders unlikely any single solution. It is a monumental task to make the administrative state's published works accessible to those actually impacted by the extant regulatory maze.

Nonetheless, even the most cynical bureaucrat, lawyer, businessperson, or citizen should favor well organized, easy to understand, and clear regulations. Accordingly, the public wo uld benefit if Congress required regulators to use this book.

Over time, however, fixing individual rules in the Code of Federal Regulations is not the answer. ${ }^{63}$ Culture change is required. An outside consultant might encourage the government to hire a cadre of strong writers to draft its regulations. Unfortunately, replacing any significant

${ }^{61}$ This seems inconsistent with the admonition, in core idea seven, that cross-referencing is superior to the use of a definitions section.

${ }^{62}$ Some drafting professionals, particularly attorneys, may prefer the less current, but more comprehensive approach offered by DICKERSON, supra note 13. Conversely, my guess is that most agency policy makers would find Murawski's work more accessible. Murawski's book contains sufficient content to make the point, without overwhelming the topic in an intimidating package.

${ }^{63}$ Nonetheless, some agencies revised their regulations in their entirety. See e.g., the Small Business Administration's effort, Stone, supra note 60; and the General Services Administration's wholesale revision of the General Services Administration Acquisition Regulation (GSAR), 64 Fed. Reg. 37200 (July 9, 1999) (among other things, "The GSAR, as reissued - Uses plain English to improve clarity and understanding. - Reduces the amount of regulatory material...."). 
portion of the civil service is a daunting, if not impossible, task. ${ }^{64}$ Moreover, nothing indicates that a surplus of talented regulation writers are available for conscription into government service. Accordingly, government leaders must change the existing workforce's behavior. As discussed below, cultural change requires little more than committed leadership and time, so there is ample reason to remain optimistic. ${ }^{65}$

\section{Is The Plain Language Movement Focu sed Upon Causes or Symptoms?}

One of the most difficult issues confronting the plain language movement is whether the effort to write more readable regulations addresses the problem's root cause or merely suppresses its symptoms. In this regard, I find Professor David Mellinkoff's work informative. ${ }^{66}$ Almost four decades ago, Mellinkoff recognized the same problems but, in response, focused primarily on the issue of legal writing's intelligibility. Rather than prescribing a re-invention of the wheel, he suggested that legal writing should be viewed through three lenses. To so me extent, much of this analysis depends upon knowledge of the author's audience. First, with regard to professional-toprofessional communications, Mellinkoff concludes that jargon is fine. ${ }^{67}$ Rather than being an object of ridicule, jargon has a place and may enhance efficiency in communication. Jargon, in this context, is a shorthand for people in the know. service laws).

${ }^{64}$ See e.g., Barr, supra note 2 (reflecting the NPR's failure to overhaul outdated civil

${ }^{65}$ See generally, Steven L. Schooner, Book Review: Change, Change Leadership, and Acquisition Reform, 26 PuB. Cont. L. J. 467 (1997).

${ }^{66}$ Mellinkoff, Language of the Law, supra note 18. See also David Mellinkoff, Legal Writing: SENSE AND Nonsense (1982). Mellinkoff has been recognized as the grandfather of the legal profession's plain language movement. WILSON, supra note 27, at 6 .

${ }^{67}$ Mellinkoff, Language of Law, supra note 18, at 421. 
Mellinkoff is less tolerant of jargon when these efficiencies do not apply. Accordingly, the second scenario - in which a layperson struggles with legal language - highlights inefficient communication that likely leads to frustration and confusion. ${ }^{68}$ Here, Mellinkoffadvises authors to eliminate unnec essary jarg on. Conc eding that jargon sometimes cannot be avoided, Mellinkoff suggests that writers define terms of art that cannot be avoided. In the third scenario, Mellinkoff seems most closely aligned with Murawski. Both agree that poor writing deserves no defense. ${ }^{69}$ Mellinkoff derides (as we all should) basic unintelligible writing. But Mellinkoff claims that lack of understanding has little to do with profligate use of terms of art. Bad writing is simply bad writing. Unfortunately, Mellinkoff concludes, lawyers fall into the habit of using forms that make writ ing unintelligible from the standpoint of English composition. Once they become comfortable with drafting nonsense, it becomes difficult to unlearn those habits. Mellink off, like Murawski, suggests a formulaic remedy that could improve most legal writing and, in the same manner, most regulations..$^{70}$

${ }^{68}$ Mellinkoff, Language of LAw, supra note 18 , at 422.

69 Mellinkoff, Language of Law, supra note 18, at 422-23.

70 To this end, Mellink off o ffers seven rules, which are developed at length throughout his thoughtful work:

(1) Peculiar: The Language of the law is more peculiar than precise. Don't confuse peculiarity with precision. (2) Precise: Don't ignore even the limited possibilities of precision. The price of sloppy writing is misunderstanding and creative misinterpretation. (3) English: Follow the rules of English composition. (4) Clear: Usually you have a choice of how to say it. Choose clarity. (5) Law: Write law simply. Do not puff, mangle, or hide. (6) Plan: Before you write, plan. (7) Cut! Cut it in half! 


\section{Can Plain English Drafting Improve Regulation?}

Of course, right-thinking minds should agree that clear, precise regulations are preferable to vague, ambiguous mandates, rules, or instructions. If, as a matter of policy and practice, the executive branch committed itself to improving the clarity of its written communication, it would be a public good. Not everyone agrees. Unclear, vague, and imprecise regulatory language has its place. ${ }^{71}$ For example, when faced with difficult or contentious statutory mandates, regulatory drafters often abdicate their interpretive responsibilities by simply parroting the statutory text. ${ }^{72}$

\footnotetext{
${ }^{70}($...continued $)$

Mellinkoff, Sense And Nonsense, supra note 18, at xvii.

${ }^{71}$ It is neither irrational nor novel to suggest that the absence of specificity and/or clarity
} are preferable in regulating certain types of conduct. See e.g., Edward B. Rock, Saints and Sinners, How Does Delaware Corporate Law Work?, 44 UCLA L. Rev. 1009, 1099 (1997) ("For present purposes, it is useful to assume that the Delaware system is pretty good and to ask, speculatively, how might such a system, which may seem rather odd and fuzzy, both in comparison to other areas of U.S. law and in comparison to the corporate law of other advanced industrial economies, end up working reasonably well?"); DICKERSON, supra note 13, at 28-29 (citations omitted) ("Unlike ambiguity, which is always bad, vagueness is often desirable .... Optimum clarity for the draftsman is found in language that achieves a degree of precision commensurate with the client's objectives.").

${ }^{72}$ See e.g., the Federal Acquisition Streamlining Act of 1994, Pub. L. No. 103-355 § 1091(b)(2), __ Stat. _ , (codified in scattered sections of 41 U.S.C. and 10 U.S.C.) (amending 41 U.S.C. § 405) ("In the case of an offeror with respect to which there is no information on past contract performance or with respect to which information on past contract performance is not available, the offeror may not be evaluated favorably or unfavorably on the factor of past contract performance."). To the extent that affected communities proved unable to agree on a methodology for implementing this statutory requirement, it was basically repeated in the Federal Acquisition Regulation, 48 C.F.R. § 15.305(a)(2)(iv): "In the case of an offeror without a record of relevant past performance or for whom information on past performance is not available, the offeror may not be evaluated favorably or unfavorably on past performance." While this practice may prove convenient for regulatory drafters, it is unhelpful to the parties affected by the regulation. 
While this practice may save time and speed the regulation's promulgation, this behavior breeds confusion and inefficiency.

Further, there are social costs and benefits of the plain language movement? Re-writing is time consuming, and agencies confront sufficient impediments to simply promulgating mandated regulations. ${ }^{73}$ Changing rules potentially increases uncertainty with regard to previously

${ }^{73}$ See generally Richard J. Pierce, Jr., Judicial Review of Agency Actions in a Period of Diminishing Agency Resources, 49 ADMIN. L. REV. 61, 64 (1997) (citations omitted), suggesting that:

For the foreseeable future, agencies will have access to constantly diminishing resources to implement their statutory mandates. It is highly unlikely that Congress will reduce the statutory responsibilities of agencies to ... create event a rough proportionality between the responsibilities assigned ... and the resources available.... Indeed, Congress is poised to increase the statutory mandates applicable to agencies in ways that will increase still further the yawning gap.... 
interpreted regulations, standard contract clauses, etc. ${ }^{74}$ Does the public benefit if the regulations are more accessible to the public? Does the public benefit if the regulations are more clear?

\section{What Does the Future Hold for Readable Regulations?}

The incoming Bush administration do well to embrace, adopt, or, if need be, "re-invent" the plain language initiative. Despite the progress made, it will take some time before a commitment to writing in plain, clear, precise English becomes a cultural (or governmental) norm. Adoption of such a norm likely would not occur without sustained commitment - of the type exhibited by the NPR - in the White House.

In order to maintain an effective plain language mandate, pressure must be applied to at least two key points. ${ }^{75}$ First, agency heads must send to drafting teams a firm message that plain

${ }^{74}$ See e.g., the caution contained in the ABA's resolution supporting Plain English, supra, note 23. Professor Ralph Nash suggests to the Federal Acquisition Regulation (FAR) drafters that:

Moving definitions around and making seemingly modest reo rganizations in the FAR can change the rules substantively. It is therefore imperative that these "minor" changes be carefully analyzed to ensure that they do not make unintended substantive rule changes....

Don't worry too much about the Government's "plain language" requirement. So far, the FAR rewrites haven't made much change in this regard, which means either that the rewriting groups don't know how to write "plain language," or they have concluded that the FAR language is already "plain." . . I If language must be legalistic to be clear, so be it. After all, the FAR has serious legal implications.

Ralph C. Nash, Jr., Rewriting the FAR: The "Plain Language” Effort, 14 NASH \& CiBINIC ReP. I 54 at 157 (Oct. 2000).

${ }^{75}$ Although some may perceive that the FEDER AL REgister staff could take an active role (continued...) 
language matters. To be effective, agency heads must communicate their vision, reinforce that communication with training, and lead by example. For training to be effective, agencies must invest scarce resources to provide drafters with both the money and the time to participate in writing workshops. Drafting teams must be required to read and become inculcated with the principles espoused in Murawski's book (or, of course, a comparable alternative). Agency heads may use outside focus groups to insure that key constituencies understand language before submitting it to the Federal Register. Some agencies may require as little as an internal memorandum. Others may need more concrete demonstrations of the agency head's commitment, such as rejecting a draft with clear instructions for remedying perceived inadequacies. Second, additional personnel, properly trained to identify and correct poor writing, could be employed by OIRA, the White House's veto-gate through which regulations pass on their way to the Federal Register.

To the extent that cost-benefit analysis only recently achieved prominence in our administrative state, it seems disingenuous to argue that the marginal cost of clear communication is not worth the investment. Who can argue with the assertion that parties governed by regulations should understand - easily and unequivocally - those rules that govern their behavior. Given the painstaking process of regulatory drafting and promulgation, coupled with the difficulty associated with extinguishing or even modifying published regulations, ad ditional care in crafting regulatory language seems warranted. Unfortunately, efforts to convert the federal government's regulations into plain language remains an evolving initiative, not a deeply ingrained mandate.

\footnotetext{
${ }^{75}$ (...continued)
}

in quality control of agency submissions, I find this option untenable. 
Only sustained, committed leadership can ensure that those who govern communicate clearly with the go verned. In a demo cracy, it is a shame that clear communication remains an aspiration, rather than a norm. 